\title{
The Influence of Financial Capital, Human Capital, and Natural Resources Capital on Economic Growth and Its Impact on Community Welfare in the Industrial Area of Batam City of Riau Island Province
}

\author{
Dhenny Asmarazisa $^{1 *}$, Tri Ratnawati ${ }^{2}$, Nekky Rahmiwati ${ }^{3}$ \\ ${ }^{1}$ Program Management Studies, University of Riau Kepulauan, Riau Islands, Indonesia \\ ${ }^{2,3}$ Faculty of Economic, University of 17 Agustus 1945, Surabaya, Indonesia
}

DOI: 1 10.36348/sjef.2020.v04i07.002 $\quad$ | Received: 25.06.2020 | Accepted: 06.07.2020 | Published: 12.07 .2020

*Corresponding author: Dhenny Asmarazisa

\section{Abstract}

This study seeks to find out and analyze in more depth the effect of financial capital, human capital, and natural resource capital on economic growth and its impact on the welfare of society in the Batam City Riau Islands Province industrial area. The population in this study is the people who live in the industrial areas of the islands of Batam. Testing of the model in this study, with Generalized Least Square Estimation (GLS), structural equation modeling (SEM) analysis, proportional random sampling method and Amos 24 software assistance, on 240 respondents from 10 times (19 indicators +5 variables). The test results show that the model (fit) can be seen from the values of GFI, AGFI, TLI, CFI, RMSEA and CMIN / DF, each of which is $0.915,0.901,0.949,0.953,0.063$ and 1.376 all within the range of expected values so that the model can be accepted. The results showed that: 1). Financial capital has a significant effect on economic growth. 2). Financial capital has no significant effect on people's welfare. 3). Human capital has a significant effect on economic growth. 4). Human capital has a significant effect on people's welfare. 5). Natural resource capital has a significant effect on economic growth. 6). Natural resource capital has a significant effect on people's welfare. 7). Economic growth has a significant effect on community welfare in the Riau Islands Industrial Area.

Keywords: Financial capital, human capital, natural resource capital, economic growth, community welfare.

Copyright @ 2020: This is an open-access article distributed under the terms of the Creative Commons Attribution license which permits unrestricted use, distribution, and reproduction in any medium for non-commercial use (NonCommercial, or CC-BY-NC) provided the original author and source are credited.

\section{INTRODUCTION}

Batam is part of Riau Islands Province, Batam is a reflection of Riau Islands Province, Batam is an island bounded by the sea, the area consists of land: $969.00 \mathrm{Km} 2$ and Ocean $601.35 \mathrm{Km} 2$, the population is 702,029 people per July 2006. The administrative area is sub-district 12, There are 64 villages which are bordered in the North of the Singapore Strait, in the east of Bintan Regency, in the southern part of Lingga Regency and in the west bordering Karimun Regency. Batam is one of the islands located between the waters of the Malacca Strait and the Singapore Strait. There is no literature that can be a reference from where the name Batam was taken, which is clear the island of Batam is a large island of 329 islands in the city of Batam. The only source that clearly mentions the name of Batam and can still be found today is Tratak London.

Mahyudi [1] states that, economic development is a branch of economics that aims to analyze the problems faced to obtain ways / methods of resolution in economic development, especially in developing countries so that economic development becomes faster and more harmonious.

Priyono (2018) states that there are two peaks of traditional annual inflation in Indonesia. The December - January period always brings higher prices due to Christmas and New Year celebrations, while traditional flooding in January (in the middle of the peak of the rainy season) results in disruption of distribution channels in some areas and cities, resulting in higher logistics costs. The peak of the second inflation occurred in the period July - August. The inflationary pressure in these two months emerged as a result of holiday periods, Muslim holy fasting month (Ramadan), Eid Al-Fitr celebrations, and commencement of the new school year. Significant increases can be detected in spending on food and other consumables (such as clothing, bags, and shoes), along with retailers adjusting prices up. 
Sanusi [2] states that growth and development are different, economic growth rests on the process of increasing the production of goods and services in community economic activities. It was further explained that growth was used in dynamics theory as developed by Neo Keynes and Neo Classical thinkers. Meanwhile, economic development implies a broader meaning and includes changes to the overall economic structure of society. Adi [3] states that financial capital is financial support that is owned by a community that can be used to finance the development process that is held in that community. Furthermore, Irawan and Suparmoko [4] suggest that financially the sources of funds for development can be grouped as follows: (a) community savings (voluntary saving), (b) taxes or called forced savings, (c) government savings; (d) government loans; (d) inflation (invisible tax); (e) foreign direct investment.

Gaol [5] Human capital is the sum of knowledge, skills, experience, and other relevant workforce attributes that reside in an organisation's workforce and drive productivity, performance, and the achievement of strategic goals. Relatively the role of natural resources is getting smaller, but if we pay attention it seems that the more advanced an economy in absolute terms the more the number and kinds of natural resources that are potential to become real natural resources [4].

Community welfare is a condition that shows the state of community life that can be seen from the standard of living of the community [6]. According to Todaro and Stephen C. Smith [7], community welfare shows a measure of the results of community development in achieving a better life which includes: first, increasing ability and equitable distribution of basic needs such as food, housing, health, and protection; second, an increase in the level of life, income level, better education, and increased attention to culture and human values; and third, expanding economies of scale and the availability of social choices from individuals and nations.

\section{Conceptual Framework}

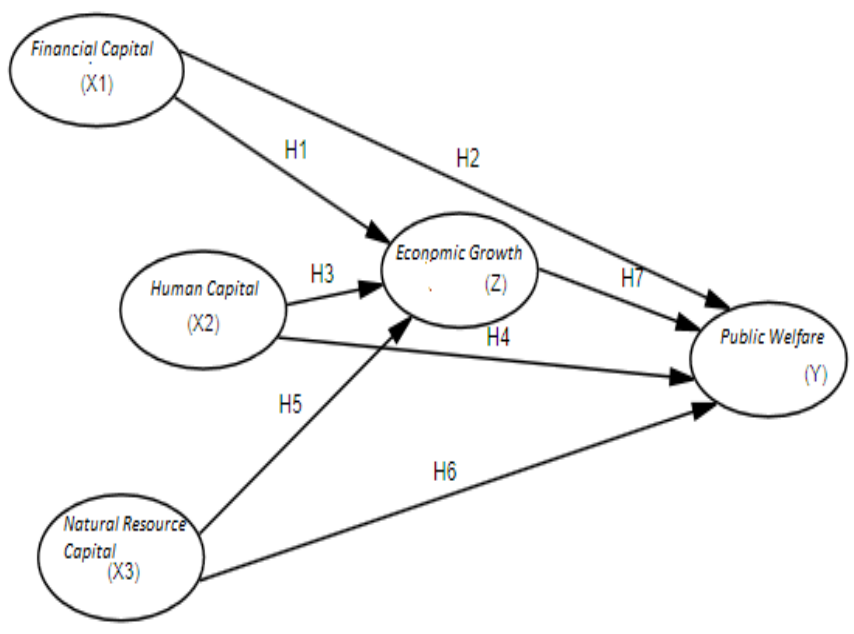

Fig-1: Conceptual Framework

\section{RESEARCH METHODOLOGY}

This research is a research that explains the causal relationship (causal explanatory) causal relationship between independent variables, namely financial capital, human capital, natural resource variables, intervening variables, namely economic growth variables and dependent variables (dependent variable) ) namely public welfare.

\section{Population and Sample}

Population is all members who are expected to be used to make decisions [8]. In this study, the observed population was the people living in the industrial area of Batam City. Sampling in this study was conducted using a purposive sampling method that was adjusted to the purpose of the study. The estimation used is Generalized Least Square Estimation (GLS), and the number of samples studied was 240 respondents, coming from 10 times (19 indicators +5 variables) in this study.

\section{Data Analysis Techniques}

After the research data has been collected, the next step is to conduct data analysis. Data analysis was performed using SEM (Structural Equation Modeling).

\section{Test Validity and Reliability Validity Test}

Validity shows how precisely an instrument measures a certain concept that must be measured. This means, validity is concerned whether the instrument used to measure an attribute, really measures the intended attribute, so that it can be seen whether the instrument is useful or not.

\section{Reliability Test}


Reliability is a measure of the internal consistency of indicators of a construct that shows the degree to which each indicator indicates a common construct / latent factor [9].

\section{RESULT AND DISCUSSION Validity Test}

Validity means also the extent to which a measuring device measures what you want to measure [10]. How to measure validity can use internal consistency (internal consistency), namely the Pearson product moment correlation method. If the correlation between each question with a total score shows a significant result (significance $<0.05$ and correlation> 0.4 ), then the question item is valid which means it has construct validity.

\section{Reliabilty Test}

Reliability measurement can also use the Cronbach alpha coefficient $(\alpha)$ which shows how well the question item is positively related to the other question items. If the Cronbach alpha coefficient is 0.6 or more, the research data are considered to be good enough or reliable to be used as input for data analysis [11]. Hair et al., [11] also states that the total corrected item total correlation is 0.3 so that the question items can be used in further data processing.

\section{Normality Test Data}

The normality of the data distribution is evaluated through skewness and kurtosis values, variables that have a coefficient of skewness or kurtosis with a critical ratio of more than \pm 8.58 indicating an abnormal distribution, and vice versa meaning normal
[9]. From the test it is known that all manifest variables totaling 71 question items have a critical ratio below \pm 8.58 , so that it is declared normal.

\section{Measurement Research Model}

Measurement model is a modeling process in research aimed at investigating the undimensionality of indicators that explain a factor or a latent variable [9]. This research data is processed using AMOS 24, before reviewing the measurement model of each variable in this study, the dimensions of the indicators that make up each variable will first be analyzed. Based on the nature of numbers, which are getting closer to zero the smaller the value in this study the magnitude of the regression value that exists between the dimensions with indicators, or between indicator variables (loading factor) with construct variables is translated as follows:

$$
\begin{aligned}
& \leq 0.40 \text { : Relationship is weak } \\
& 0.41-0.55: \text { Medium relationship } \\
& 0.56-0.69: \text { Strong relationship } \\
& \geq 0.70 \text { : Relationships are very strong }
\end{aligned}
$$

\section{Research Model Structure}

He structure of the model is used to describe models of causality research with a tiered relationship. The initial research model (Proposed Model) that has been created, analyzed with structural equation models (structural equation models) with the help of AMOS 24 software. Structural equations (structural equation models) with the help of AMOS 24 software. The results of the analysis of the initial model (independence model) can be seen in Figure

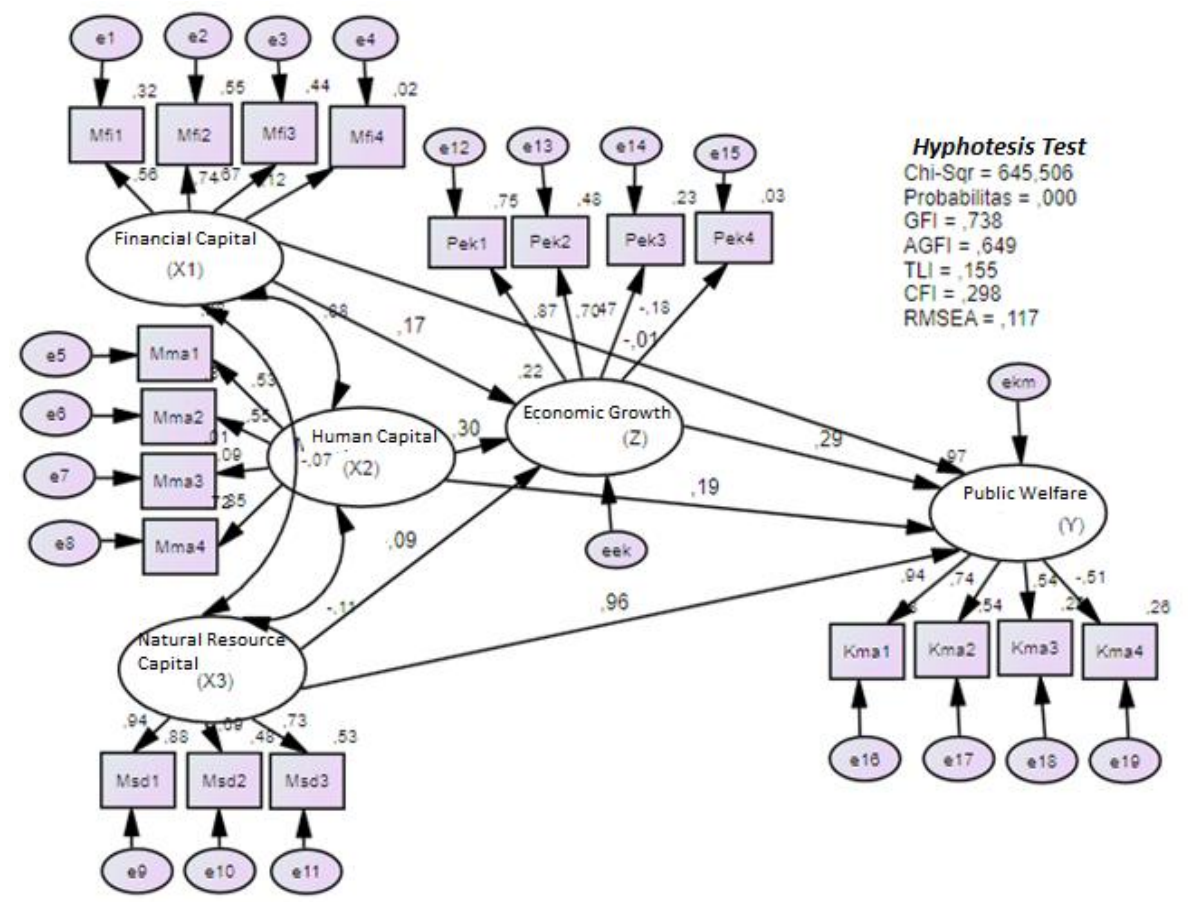

Fig-2: Structural Early Research Model 
Table-1: Goodness of Fit Index Test Results Structrual Proposed Model

\begin{tabular}{|l|l|l|l|l|}
\hline No & Goodness of Fit Index & Cut-off Value & Model Test Result & Information \\
\hline 1 & $\chi 2 /$ Chi-Square & & 645,506 & Must be small \\
\hline 2 & Significance probability & $\geq 0,05$ & 0,000 & Less \\
\hline 3 & GFI & $\geq 0,90$ & 0,738 & Less \\
\hline 4 & AGFI & $\geq 0,90$ & 0,649 & Less \\
\hline 5 & TLI & $\geq 0,95$ & 0,155 & Less \\
\hline 6 & CFI & $\geq 0,94$ & 0,298 & Less \\
\hline 7 & RMSEA & $\leq 0,08$ & 0,117 & Less \\
\hline 8 & Relative $\chi 2(\mathrm{CMIN} / \mathrm{DF})$ & $\leq 2,00$ & 4,546 & Less \\
\hline
\end{tabular}

Source: Prefared research with Amos

Goodness of fit analysis shows that the probability is equal to zero (chi square value is large) so that the null hypothesis cannot be rejected, or accept the null hypothesis which states that the sample covariance and population covariance are not the same. Besides that, there are several other criteria of goodness of fit that have not been met, such as TLI, GFI, AGFI and RMSEA, whose values are only close to the desired range.
But from the evaluation of the regression weight, all variables have a causal relationship and have a critical ratio value not equal to zero. This indicates that the research model is accepted. Therefore, in this study no modification of the model was carried out by modifying the index

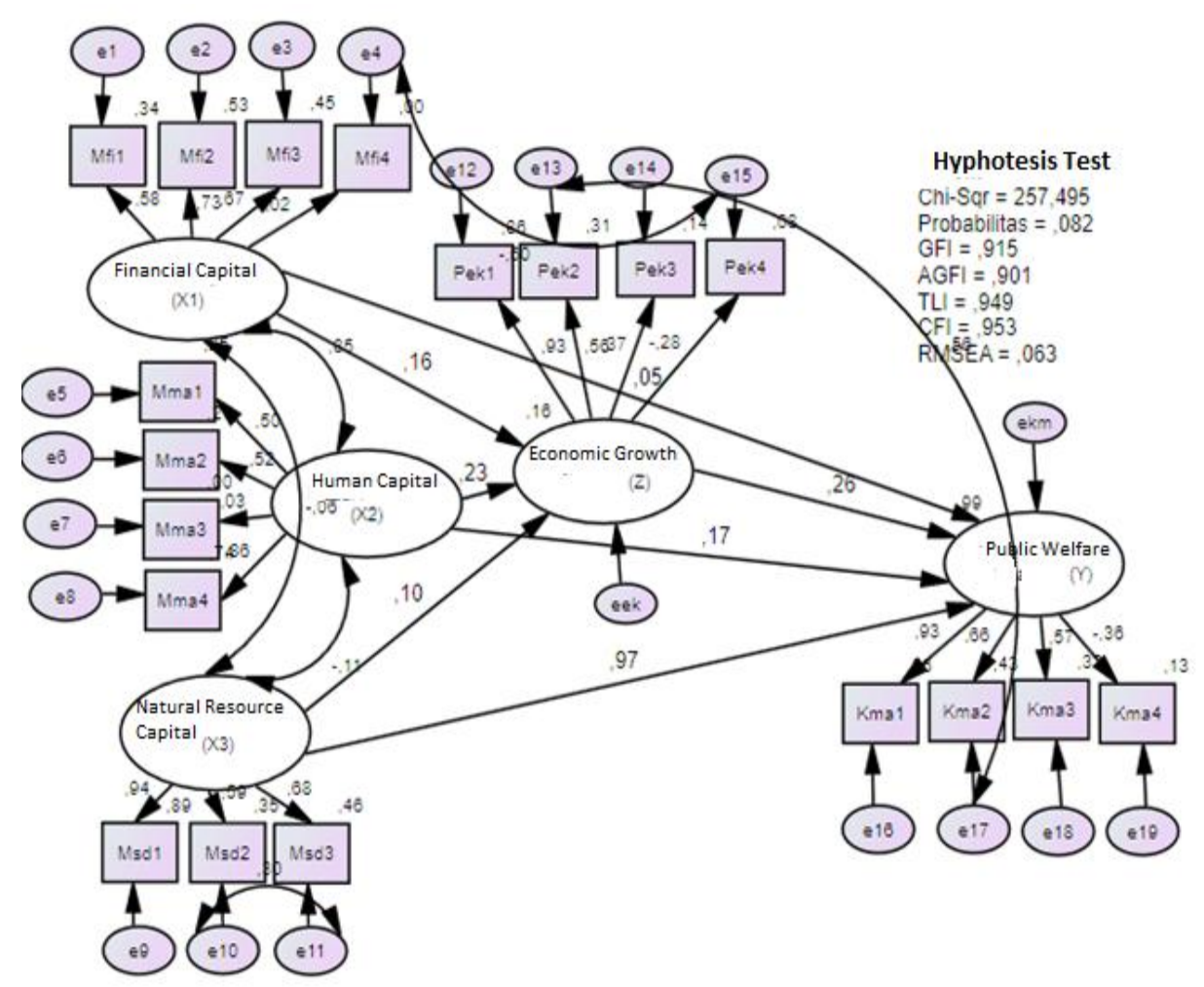

Fig-3: Structural Research Model (final Model)

Test of Conformity Model (Goodness of Fit Test)

The results of data processing using a sample of 240 shows the level of significance for the hypothesis test of the difference above is 257,495 with a probability of 0.082 . This shows that there is no difference between the sample covariance matrix and the population covariance matrix, so the null hypothesis is accepted (accepted if probability $\geq 0.05$ ). Meanwhile the values of GFI, AGFI, TLI, CFI, RMSEA and CMIN / DF are 0.915, 0.901, 0.949, 0.953, 0.063 and 1.376, respectively within the expected value range so that the model can be accepted. 
Table-2: Test Result Goodness of Fit Index Structural Final Model

\begin{tabular}{|l|l|l|l|l|}
\hline No & Goodness of Fit Index & $\begin{array}{l}\text { Cut-off } \\
\text { Value }\end{array}$ & Model Test Result & Information \\
\hline 1 & $\chi 2$ / Chi-Square & & 257,495 & Good \\
\hline 2 & Significance probability & $\geq 0,05$ & 0,082 & Good \\
\hline 3 & GFI & $\geq 0,90$ & 0,915 & Good \\
\hline 4 & AGFI & $\geq 0,90$ & 0,901 & Good \\
\hline 5 & TLI & $\geq 0,95$ & 0,949 & Good \\
\hline 6 & CFI & $\geq 0,95$ & 0,953 & Good \\
\hline 7 & RMSEA & $\leq 0,08$ & 0,063 & Good \\
\hline 8 & Relative $\chi 2(\mathrm{CMIN} / \mathrm{DF})$ & $\leq 2,00$ & 1,376 & Good \\
\hline
\end{tabular}

Source: Prefared Researcher

\section{Parameter Testing}

To find out the causality relationship between each variable, a null hypothesis test was conducted which said that the regression coefficient between relationships was equal to zero through the $t$ test in its regression model. Table- 3 shows that the magnitude of the regression between the variables of financial capital and economic growth of the community is 0.156 and the value of $C R=2.592$, meaning that the financial capital variable has a significant effect on economic growth. The magnitude of the regression between the variables of natural resources with economic growth of 0.106 and the value of $\mathrm{CR}=2.155$, meaning that the variable of natural resources has a significant effect on economic growth. The magnitude of regression between the variables of human capital with economic growth of 0.235 and the value of $\mathrm{CR}=2.901$, meaning that the variable of human capital has a strong and significant effect on economic growth. The magnitude of the regression between the variables of natural capital capital with the welfare of the community is 0.969 and the value of $\mathrm{CR}=12.938$, meaning that the variable of natural capital has a strong and significant effect on people's welfare. The magnitude of the regression between the variables of human capital with the variable community welfare is 0.174 and the value of $\mathrm{CR}=2.149$, meaning that the variable of human capital has a significant effect on people's welfare. The magnitude of the regression between the variables of economic growth with the variable social welfare of 0.259 and the value of $\mathrm{CR}=4.127$, meaning that the variable of economic growth has a strong and significant effect on people's welfare. The magnitude of the regression between the variables of financial capital with the variable social welfare of 0.051 and the value of $\mathrm{CR}=0.314$, meaning that the variable of financial capital has no significant effect on people's welfare.

Table-3: Estimation of Final Parameter Model

\begin{tabular}{|l|l|l|l|l|l|l|}
\hline \multicolumn{2}{|l|}{ Relationship Structure } & Path coefficient & Value C.R & P_value & Information \\
\hline FIN & $\rightarrow$ & EKO & 0,156 & 2,592 & 0,004 & Significant \\
\hline FIN & $\rightarrow$ & MAS & 0,051 & 0,314 & 0,754 & Not Significant \\
\hline MAN & $\rightarrow$ & EKO & 0,235 & 2,901 & 0,000 & Significant \\
\hline MAN & $\rightarrow$ & MAS & 0,174 & 2,149 & 0,001 & Significant \\
\hline ALM & $\rightarrow$ & EKO & 0,106 & 2,155 & 0,008 & Significant \\
\hline ALM & $\rightarrow$ & MAS & 0,969 & 12,938 & 0,000 & Significant \\
\hline EKO & $\rightarrow$ & MAS & 0,259 & 4,127 & 0,000 & Significant \\
\hline
\end{tabular}

Source: Prefared Researcher

Coefficient of Determination Analysis ( $\left.\mathbf{R}^{2}\right)$

Analysis of influence between latent variables is done to test how much the contribution of influence between latent variables is formed or the percentage of variance between variables can be explained as shown in Table-4.

Table-4: Coefficient of Determination $\left(\mathbf{R}^{2}\right)$

\begin{tabular}{|l|l|l|}
\hline Laten Variables & $\begin{array}{l}\text { Square Multiple } \\
\text { Correlation }\left(\mathbf{R}^{2}\right)\end{array}$ & Information \\
\hline Economic Growth (Z) & 0,858 & The Influence of X1, X2, X3 together against Z is 85,8\% \\
Welfare Community (Y) & 0,990 & Contribution of Influence X1, X2, X3, and Z together to Y equal 99,0\%. \\
\hline
\end{tabular}

Source: Results of the Processed Researcher

Table-4, shows the following:

A. $85.8 \%$ of the variance in economic growth variables can be explained by factors of financial capital, human capital, and natural resource capital. While the rest is explained by other variables not found in this study.
B. $99.0 \%$ of the variance on public welfare variables can be explained by factors of financial capital, human capital, natural resource capital, and economic growth. While the rest is explained by other variables not found in this study. 


\section{Hyphotesis Test 1}

Financial Capital has a significant effect on economic growth in the Batam Riau Islands Industrial Area. There is an influence of financial capital on economic growth in the Batam City Industrial area of 0.156 , with a $C R$ value of 2.592 . This means that existing financial capital in the community in Batam City, Riau Islands Province, will increase economic growth by $15.6 \%$. This means that hypothesis 1 is accepted.

\section{Hyphotesis Test 2}

Financial Capital does not significantly influence the welfare of the people in the Riau Islands Industrial Estate. There is an influence of financial capital on community welfare in the Batam Kepri Industrial area of 0.051 with a CR value of 0.314 . This means that financial capital in the city of Batam, Riau Islands Province, has not been able to improve the welfare of the people in Batam City, Riau Islands Province. This means that hypothesis 2 is rejected.

\section{Hyphotesis Test 3}

Human capital has a significant effect on people's welfare. There is an influence of human capital on the welfare of the community in Batam City, Riau Islands Province, amounting to 235 with a CR value of 2.901. This means that human capital in the City of Batam, Riau Islands Province, can improve people's welfare by $23.5 \%$. This means that hypothesis 3 is accepted.

\section{Hyphotesis Test 4}

Human capital has a significant effect on economic growth in the Batam City Industrial area. There is an influence of human capital on economic growth in the Batam City Riau Islands Industrial area of 0.235 with a $C R$ value of 2.901 . This means that the human capital of the City of Batam, Riau Islands, will be able to increase economic growth in the Batam City
Batam Industrial Area by $23.5 \%$. This means that hypothesis 4 is accepted.

\section{Hyphotesis Test 5}

Natural resource capital has a significant effect on economic growth in the Batam City Industrial area. Table 5.24, shows that there is an influence of natural resource capital on community economic growth of 0.106 with a $C R$ value of 2.155 . This means that in this study, the natural capital of Batam City can increase economic growth in Batam City in the Riau Islands Province by $120.6 \%$. This means that hypothesis 5 is accepted.

\section{Hyphotesis Test 6}

Natural resource capital has a significant effect on community welfare in the Batam City Industrial area. There is an influence from the natural capital of the City of Batam in the Riau Islands Province on the welfare of the people in the Batam City Industrial Area of 0.969 , with a CR value of 12.938 . This means that natural resource capital has a significant effect on community welfare in the Batam Islands Batam City Industrial area. This means that hypothesis 6 is accepted.

\section{Hyphotesis Test 7}

Economic growth has a significant effect on community welfare in the Batam City Industrial area. There is an influence of the economic growth of the community on the welfare of the community in the Batam City Riau Islands Industrial area of 0.259 with a CR value of -4.127 . This means that economic growth has a significant effect on the welfare of the community in the Batam City Riau Islands Industrial area. This means that hypothesis 7 is accepted. From the results of the analysis that has been done, the details of the results of the hypothesis test in this study are shown in Table5 .

Table-5: Research Hyphotesis Test Result

\begin{tabular}{|l|l|l|}
\hline Hyphotesis & STATEMENT & Result \\
\hline First & Financial Capital has a significant effect on economic growth in the Batam Industrial area. & Be Accepted \\
\hline Second & Financial Capital has a significant effect on community welfare in the Batam Industrial area. & Rejected \\
\hline Third & Human capital has a significant effect on economic growth in the Batam Industrial area & Be Accepted \\
\hline Fourth & Human capital has a significant effect on community welfare in the Batam Industrial area. & Be Accepted \\
\hline Fifth & $\begin{array}{l}\text { Natural resource capital has a significant effect on economic growth in the Batam Industrial } \\
\text { area. }\end{array}$ & Be Accepted \\
\hline Sixth & $\begin{array}{l}\text { Natural resource capital has a significant effect on community welfare in the Batam } \\
\text { Industrial area. }\end{array}$ & Be Accepted \\
\hline Seventh & Economic growth has a significant effect on community welfare in the Batam Industrial area. & Be Accepted \\
\hline
\end{tabular}

Source: The Result of Processed Researcher (2020)

\section{CONCLUSIONS AND RECOMMENDATION}

This research has found that community welfare in the industrial area of Batam City, Riau Islands Province. Can be explained (influenced) significantly by the variables of financial capital, human capital, natural resource capital, and economic growth. This finding can be an alternative model or way of managing financial capital, human capital, natural resource capital, and economic growth with the aim of 
increasing the welfare of the community in the industrial area of Batam City, Riau Islands Province.

Financial Capital has a significant effect on economic growth in the Batam City Industrial Area. The coefficient of financial capital variable path to economic growth in the Batam City Industrial area is 0.156 with a critical ratio (CR) value of 2.502 and a probability value of 0.004 . The probability value is smaller than 0.05 , this indicates the influence of financial capital variables on economic growth in the Batam City Industrial area is significant or can be trusted. While the positive value of beta explains its directional effect, it means that financial capital in the Batam City Industrial area contributes to increasing economic growth in the Batam City Industrial area, and vice versa failure in forming financial capital can reduce economic growth in the Batam City Industrial area. The contribution made in these contributions was $15.6 \%$.

Financial Capital does not significantly influence the welfare of the people in the Batam City Industrial area. The coefficient of financial capital variable path to public welfare in the Batam City Industrial area is 0.051 with a critical ratio $(\mathrm{CR})$ value of 0.314 and a probability value of 0.754 . Probability value greater than 0.05 , this indicates the influence of financial capital variables on the welfare of the community in the Batam City Industrial area is insignificant or cannot be trusted. While the positive value of beta explains its directional effect, it means that financial capital in the Batam City Industrial area contributes to increasing economic growth in the Batam City Industrial area, and vice versa failure in forming financial capital can reduce economic growth in the Batam City Industrial area. The contribution made in these contributions was $5.1 \%$.

Human capital has a significant effect on economic growth in the Batam City Industrial area the coefficient of the variable path of human capital to economic growth in the Batam City Industrial area is 0.235 with a critical ratio $(\mathrm{CR})$ value of 2.901 and a probability value of 0,000 . The probability value is smaller than 0.05 , this indicates the influence of human capital variables on economic growth in the Batam City Industrial area is significant or can be trusted. While the positive value of beta explains its directional effect, it means that human capital in the Batam City Industrial area contributes to increasing economic growth in the Riau Islands Industrial Estate, and vice versa failure in forming human capital can reduce economic growth in the Batam City Industrial Area. The contribution made in these contributions was $23.5 \%$.

Human capital has a significant effect on community welfare in the Batam City Industrial area. The coefficient of the variable path of human capital to the welfare of society in the Batam City Industrial area is 0.174 with a critical ratio (CR) value of 2.149 and a probability value of 0.001 . The probability value is smaller than 0.05 , this indicates the influence of the variable human capital on the welfare of the community in the Batam City Industrial area is significant or can be trusted. While the positive value of beta explains its directional effect, it means that human capital in the Batam City Industrial area contributes to improving the welfare of the community in the Batam City Industrial area, and vice versa failure in forming human capital can reduce the welfare of the community in the Batam City Industrial Area. The contribution made in the contribution was $17.4 \%$.

Natural resource capital has a significant effect on economic growth in the Batam City Industrial area. The variable path coefficient of natural resource capital to economic growth in the Batam City Industrial area is 0.106 with a critical ratio $(\mathrm{CR})$ value of 2.155 and a probability value of 0.008 . The probability value is smaller than 0.05 , this indicates the influence of natural resource capital variables on economic growth in the Batam City Industrial area is significant or can be trusted. While the positive value of beta explains its directional effect, it means that natural capital capital in the Batam City Industrial area contributes to increasing economic growth in the Batam City Industrial area, and vice versa failure in forming natural capital capital can reduce economic growth in the Batam City Industrial area. The contribution made in these contributions was $10.6 \%$

Natural resource capital has a significant effect on community welfare in the Batam City Industrial area. The coefficient of the variable path of natural resource capital to the welfare of the community in the Batam City Industrial area is 0.969 with a critical ratio (CR) value of 12,938 and a probability value of 0,000 . The probability value is smaller than 0.05 , this indicates the influence of natural resource capital variables on the welfare of the community in the Batam City Industrial area is significant or can be trusted. While the positive value of beta explains its directional effect, meaning that natural capital capital in the Batam City Industrial area contributes to improving the welfare of the community in the Batam City Industrial area, and vice versa failure in forming natural capital capital can reduce the welfare of the community in the Batam City Industrial Area. The contribution made in these contributions was $96.9 \%$.

Economic growth has a significant effect on community welfare in the Batam City Industrial area. The coefficient of the variable path of economic growth to the welfare of the people in the Batam City Industrial area is 0.259 with a critical ratio (CR) value of 4.127 and a probability value of 0.000 . The probability value is smaller than 0.05 , this indicates the influence of economic growth variables on the welfare of the people in the Batam City Industrial Area is significant or can 
be trusted. While the positive value of beta explains its directional effect, it means that economic growth in the Batam City Industrial area contributes to improving the welfare of the community in the Batam City Industrial area, and vice versa failure in forming economic growth can reduce the welfare of the community in the Batam City Industrial Area. The contribution made in the contribution was $25.9 \%$.

\section{REFERENCES}

1. Adi, Isbandi Rukminto (2008). Intervensi Komunitas Pengembangan Masyarakat Sebagai Upaya Pemberdayaan Masyarakat. Jakarta: Raja Grafindo Persada

2. Agusty Ferdinand(2012). Metode Penelitian Manajemen. Penerbit Universitas Diponegoro. Semarang

3. Badrudin (2012). Ekonomika Otonomi Daerah. Yogyakarta: UPP STIM

4. Cooper \& Schindler (2011). Business Research Methods 11thed. New York: McGraw-Hill Companies Inc
5. Gaol, Jimmy( 2014). A to Z Human Capital, Jakarta : PT Grasindo.

6. Golan Amos, Jeffry M.Peloff(2001). Welfare Effect of Minimum Wage and Other Govermment Policies World Economic Forum Journal. The Free Press.

7. Hair, Jr et.al. (2010). Multivariate Data Analysis (7th ed). United States : Pearson

8. Irawan, Suparmoko dkk., (2014). Ekonomika Pembangunan. (edisi keenam). Yogyakarta. BPFE.

9. Mahyudi, Ahmad, (2014). Ekonomi Pembangunan dan Analisis Data Empiris. Bogor: Penerbit Ghalia Indonesia.

10. Priyono Effect of Wage (2018)., Inflation and Exchange Rate on the Investment Policy in Sidoarjo District, Indonesia. East Asia 35, 267292. https://doi.org/10.1007/s12140-018-9294-5

11. Priyono (2016). Esensi Ekonomi Makro, Zifatama publisher, Sidoarjo.

12. Sanusi, Bachrawi. 2014. Pengantar Ekonomi Pembangunan. PT Rineka Cipta. Jakarta.

13. Singarimbun, Masri dan Sofian Effendi (2014). Metode Penelitian Survei. Jakarta:LP3ES

14. Todaro, Michael P dan Smith, Stephen C. (2012). Pembangunan Ekonomi, Jakarta: Erlangga. 